\title{
Developmental Direction of South Korean
}

\author{
Casino Market
}

\author{
Hyungsok Kim \\ $\mathrm{Ph}$ D. Candidate, Department of Security Management \\ Kyonggi University, South Korea \\ Tel: 82-2-3466-6000Ｅmail: yline98@naver.com \\ Minwan Kang (Corresponding author) \\ Professor, Department of Security Management \\ Kyonggi University, South Korea \\ Tel: 82-31-249-9951Ｅmail: kmw@kgu.ac.kr
}

Received: May 4, 2015 Accepted: June 1, 2015 Published: June 8, 2015

doi:10.5296/rbm.v2i2.7776 URL: http://dx.doi.org/10.5296/rbm.v2i2.7776

\begin{abstract}
Korean casino market is currently in a new turning point and plans to expand more casinos in addition to the 17 casinos and talks about development of the tourism industry through massive investment of foreign capital. Casino market is such a sensitive issue in our country and except for Kang-won Land, all casinos are exclusively for foreigners. However, foreign capital has announced plans to invest substantial capital in terms of allowing locals to enter casino as well. Under these circumstances, Kang-won Land Casino is strongly claiming that allowing locals to casino is illegal under the law, but certain regions confront that amending the law on the investment is necessary for economic growth to attract more casinos. In this study, we grasp the current situation and its development of casino in Korea and set a direction for the future development of casino
\end{abstract}

Keywords: development background of Korean Casino, existing condition of Korean Casino, future development of Korean Casino

\section{Introduction}

In these days, South Korea has a great interest in the casino market and establishment of additional casinos are almost confirmed in Incheon Region. the Las Vegas Sands Corp., the largest owner of US casinos, has recently said they would like to build a 5 trillion-won ( $\$ 4.5$ billion) integrated resort in Busan, but only if the government is willing to allow locals to gamble in the casino (Busan Daily, March 12, 2015). That could potentially be a sticking point, however, it shows how much casino market is attractive business in term of profit. A foreign visitor visits casino is equal to exporting 24 of semiconductors and attracting 18 people to casino is equal to exporting a vehicle to overseas. Thus, Casino market is the high export in tourism industry (Kim et al., 2013). 
Also, casino industry that allows gambling and alcohol has been exposed to danger. Especially, the effects of alcohol are that it clouds judgement and can cause various complaints. In United Kingdom, selling alcohol in casino is prohibited, but most of casinos in the United States offer alcohols to their customers (Kim et al., 2013). In South Korea, people are allowed to drink in casinos, but people who got drunk are restricted. Also, each region runs gambling addict prevention and healing center in order to prevent the damage from gambling addiction.

As above, despite all the side effects of casino, the advantages of casino have to be complemented in order to invigorate the casino market. In this study, we grasp the current situation and its development of casino in Korea and set a direction for the future development of casino.

\section{Development Background of Korean Casino}

There are a total of 17 casinos in Korea, but 16 of them except Kanwon Land are for foreigners only and Koreans cannot play there. Kanwon Land Casino is the only casino that accepts Koreans. Part of the Kangwon Land Casino opened in 2000 and the full-scale launch was in 2003 along with the opening of the main Kangwon Land Hotel. However, the revenue and visitors of Kangwon Land is considerably more than other foreigners-only casinos. It is because Kanwon Land is the only place that permitted to admit locals. This advantage is the reason why foreign capital wants to open casinos in terms of allowing locals to enter casino. Businesses are run to make as much profit as possible for owners. Thus, foreign investors proposed this as the most important condition to open casino.

Of the 17 casinos in South Korea, only Kangwon Land can admit local gamblers. This exclusive privilege was secured with the Special Act on the Assistance to the Development of Abandoned Mine Areas. In regard to the special act, there are no regulations in renewing the permit of the workplace after the act expired and authorizing without specifying the grant period is within the discretion of administrative office. (Special Act on the Assistance to the Development of Abandoned Mine Areas article 11, paragraph 4) Basically it means that you can extend the period for the regulation of admitting locals. According to a member of the Federation of Korean Industries (FKI), he said that Korean administration should review the permission of admitting locals to casino in order to build more integrated resort (Busan Daily, March 12, 2015). According to the bill of provincial assembly, in 1989, the mine was abandoned due to unilateral enforcement of the coal rationalization policy and many residents of mining area moved to the city. Thus, the population of mine area has been devastated and the local economy has been decreased rapidly. The remaining residents protested for the right to live in the area and the government enacted the "Special Act on the Assistance to the Development of Abandoned Mine Areas" for economic recovery and development of mine area. Exceptionally, this special law has been sparked that residents are now allowed to access the casino and this exclusive casino license is valid until 2025 (Asia News, February 10, 2015). Kangwon Land Casino maintains a monopoly for Koreans under the special law, but the opponents argue that Kangwon Land has proven that Koreans are prone to gambling addiction and more casinos for local residents would foster more addicts.

These are our current situation right now and the government must accurately grasp the situation of the community in order to build additional casinos. In recent years, the Korean regulatory environment has become increasingly aimed at attracting foreign investors and developers to invest into Korea and boost Korea's tourism industry (Song et al., 2014).

Casino market is a very effective in tourism industry to promote the expenditure of foreign tourists and to extend the period of stay. Most of countries are legalizing the casino market 
and developing as a new field in tourism industry. Casino industry may include the following five of the benefits.

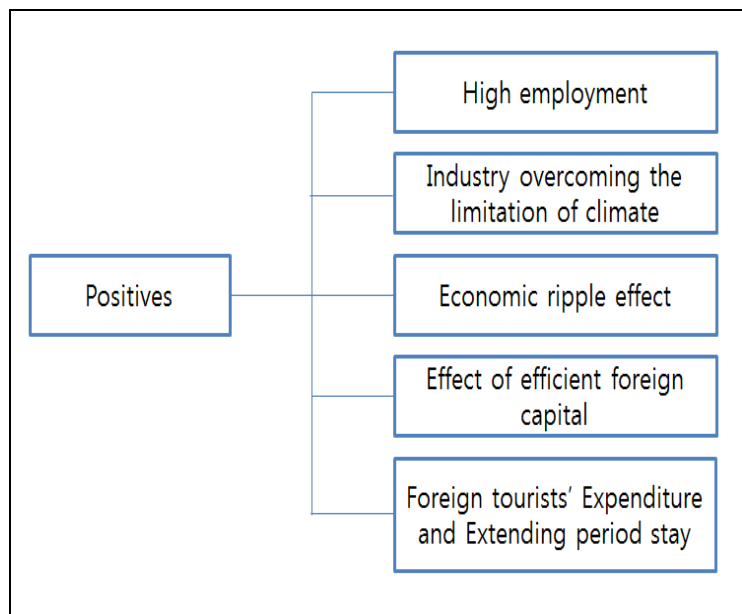

Figure 1. Positive Impact of Casino Market on the Tourism Industry

Casino is a place where many employees are needed because it provides services with manpower and it's an indoor activity that almost not influenced by weather. Also, casino market will likely have greater economic ripple effect through increase of financial revenue and creating significant added value into related industry. Attracting customers into casino market has higher influence than exports of other industries and casino can expect the effect of increasing the per capita consumption through the ability of extend the length of visit (Kim et al., 2013).

However, the social side-effects could also be generated and it can be divided into personal loss and social loss. The casino can even lead to individual economic, physical, and metal loss if gets too serious on gambling. Dissipation of wealth, family breakdown, and gambling addiction could give negative effect to individuals and families that belong to our community. Also, there is a possibility that it will stimulate gambling, money laundering, illegal financial activity, and organized crime through the social loss of casinos. For this reason, advanced countries such as the United States, Canada, and Australia have tried to minimize the side effects of casino. Each country or state has certain laws to regulate the casino and the Gaming Commission is responsible for monitoring compliance with licensing and legal framework of the casino. They also serve to minimize the personal and social loss from the gambling. (Yoon, 2013)

\section{Economic Effects of Korean Casino Industry}

Casino began to recognize as a tourism industry in modern days, its size and form has been developed. In the past, the casino industry was only for its facility, but it has developed in the form of integrated resort that includes casino, theme park, convention centre, entertainment facility, and etc. (Lee et al., 2011). Casino as tourism industry was adversely affected by a variety of economic increases depending on the size of casino (Kang \& Yuk, 2010). 
Table 1. Existing Condition of Korean Casino

2015, Vol. 2, No. 2

※ \# of Employees: Seven Luck Gangnam (Include head office), Gangwon Land (Whole resort)

'Basis on May, 2014

* Imposition of Tourism Funding: Sales Basis

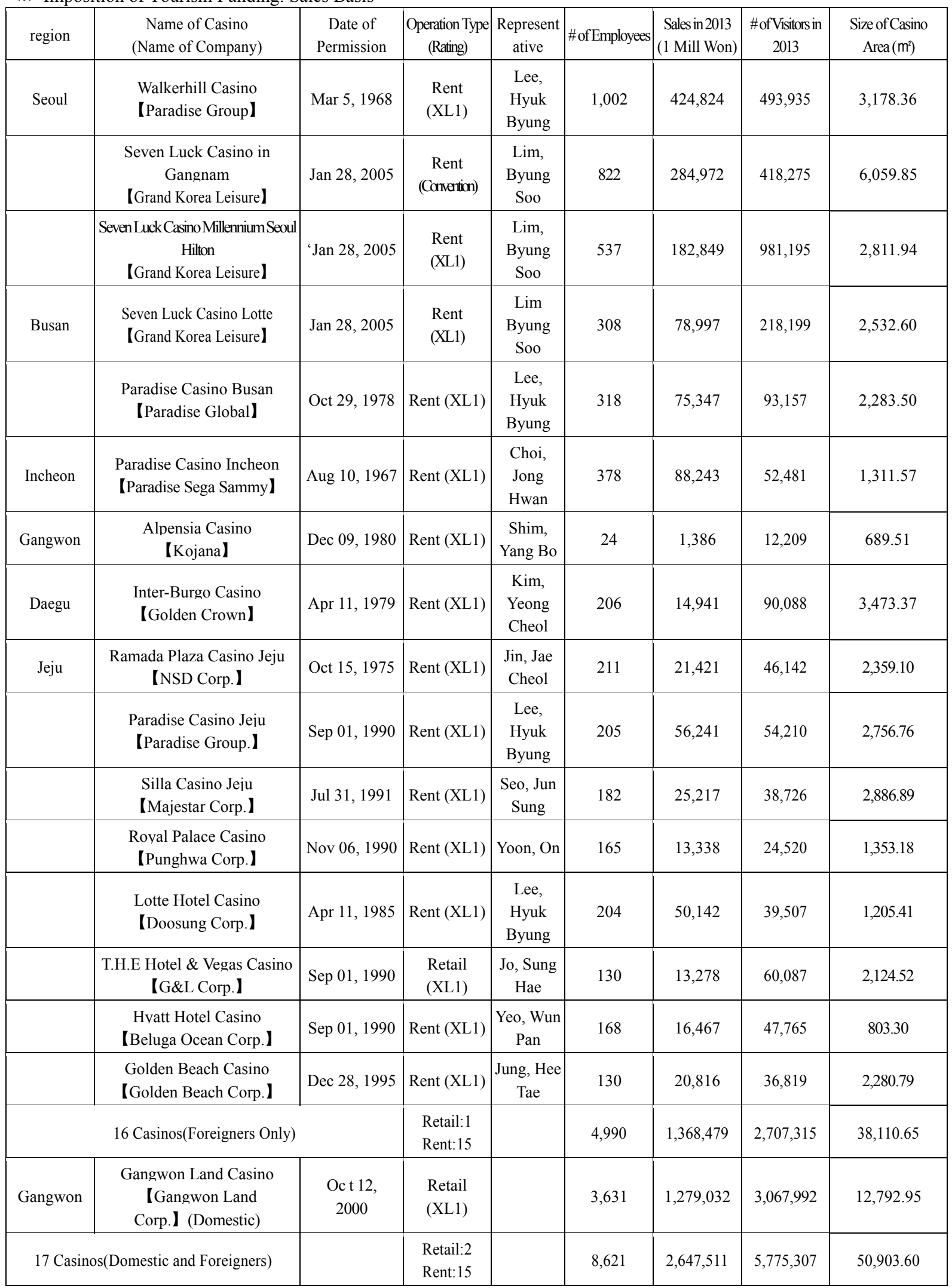

Source: Statistics of Ministry of Culture 2014. 


\section{Macrothink Mnstitute"}

Economic effects of the casino industry can be divided into two effects. Primary effect is also known as direct effect and the expenditure from foreign tourists becomes the direct revenue of the casino. The casino spends some of its revenue to purchase food materials and manufactured goods from other industries. This is called the indirect effect that generates effects on other industries. Indirect effect generates a chain ripple effect and this effect caused by the revenue and taxes will continue until the money completely leaves out of economic zone. In addition, some of the casino revenue is spent on salaries of the employees and employees spend part of their salary to purchase goods, products, etc. from other industries. The expenditure increases due to increase of employees' income and the increase in consumption augment the production effect of other industries. It is called the inductive effect. This inductive effect and indirect effect is also called secondary effect (Lee et al., 2011).

\section{Existing Condition of Korean Casino}

Existing condition of Korean Casino is shown on Table 1. Kangwon Land Casino that opens to locals recorded significantly higher sales than any other casinos and Casinos in Seoul recorded higher sales than other regions

Currently, Korean casino is growing continuously. $<$ Table $2>$ is an indicator that shows the customers visiting casino. The table shows that tourists were sustained more than $10 \%$ of market share since 1993 and has maintained its market share of over 20\% since 2009 . Although there were some fluctuations, the number of tourists visiting casino continues to rise

Table 2. Annual Foreign Tourists Compared to Casino Guests

(Unit: Person, \%)

\begin{tabular}{|c|c|c|c|c|}
\hline Year & $\begin{array}{c}\text { Foreign } \\
\text { Tourists } \\
(\mathrm{A})\end{array}$ & $\begin{array}{c}\text { Casino } \\
\text { Guests } \\
(\mathrm{C})\end{array}$ & $\begin{array}{c}\text { Market Share Compared to Foreign } \\
\text { Tourist(C/A) }\end{array}$ & $\begin{array}{c}\text { Compound Annual Growth } \\
\text { Rate (\%) }\end{array}$ \\
\hline 1993 & $3,331,226$ & 650,420 & 19.5 & $\Delta 4.4$ \\
\hline 1994 & $3,580,024$ & 625,865 & 17.5 & $\Delta 3.8$ \\
\hline 1995 & $3,753,197$ & 633,174 & 16.9 & 1.2 \\
\hline 1996 & $3,683,779$ & 517,672 & 14.1 & $\Delta 18.2$ \\
\hline 1997 & $3,908,140$ & 518,178 & 13.1 & 0.1 \\
\hline 1998 & $4,250,216$ & 689,254 & 16.0 & 33.0 \\
\hline 1999 & $4,659,785$ & 694,899 & 14.9 & 0.8 \\
\hline 2000 & $5,321,792$ & 636,005 & 12.0 & $\Delta 8.4$ \\
\hline 2001 & $5,147,204$ & 626,851 & 12.1 & $\Delta .4$ \\
\hline 2002 & $5,347,468$ & 647,722 & 12.1 & $\Delta .3$ \\
\hline 2003 & $4,753,604$ & 630,474 & 13.2 & 7.4 \\
\hline 2004 & $5,818,138$ & 677,145 & 11.6 & $\Delta 15.2$ \\
\hline 2005 & $6,022,752$ & 574,094 & 9.5 & 72.2 \\
\hline 2006 & $6,155,046$ & 988,718 & 16.1 & 19.0 \\
\hline 2007 & $6,448,240$ & $1,176,338$ & 18.2 & 8.5 \\
\hline 2008 & $6,890,841$ & $1,276,772$ & 18.5 & 31.3 \\
\hline 2009 & $7,810,000$ & $1,676,207$ & 21.5 & 16.1 \\
\hline 2010 & $8,798,000$ & $1,945,819$ & 22.1 & 8.0 \\
\hline 2011 & $9,795,000$ & $2,100,698$ & 21.4 & 13.5 \\
\hline 2012 & $11,140,000$ & $2,384,214$ & 21.4 & 13.6 \\
\hline 2013 & $12,175,550$ & $2,707,315$ & 22.2 & \\
\hline
\end{tabular}

Source: Statistics of Ministry of Culture 2014. 


\section{Macrothink MInstitute"}

Increase of visitors is the evidence that customers are interested in the casino. It is an important indicator of the size and growth and this could lead to the revenue of the casino. By looking at the $<$ Table $3>$, we can recognize the annual foreign capital compared with the revenue of the casino. The result of research that has continued since 1993, the earning of foreign capital has been growing constantly. It can be seen that earning of foreign capital is increasing by growing of Korea's tourism industry and indicates that the casino industry has a role in increasing the earning of foreign capital. Also, the annual growth rate shows over double-digits in growth. In 2007, the market share reached the highest peak and slightly decreased but, was consistently increasing. Thus, Korean casino market has been growing continuously and the government is trying to further invest in various directions.

Table 3. The Annual Foreign Capital with the Revenue of the Casino

\begin{tabular}{|c|c|c|c|c|c|}
\hline Year & $\begin{array}{l}\text { Earning of Foreign } \\
\text { Capital of Tourism } \\
\text { Industry } \\
(\text { Million } \$(A)\end{array}$ & $\begin{array}{l}\text { Annual } \\
\text { Growth(\%) }\end{array}$ & $\begin{array}{l}\text { Earning of Foreign } \\
\text { Capital of Casino } \\
\text { Industry } \\
(\text { Thousand } \$)(B)\end{array}$ & $\begin{array}{l}\text { Annual } \\
\text { Growth }(\%)\end{array}$ & $\begin{array}{l}\text { Stock Share }(\%) \\
(B / A)\end{array}$ \\
\hline 1993 & 3,474 & 6.2 & 173,176 & 27.0 & 4.9 \\
\hline 1994 & 3,806 & 9.5 & 250,763 & 44.8 & 6.6 \\
\hline 1995 & 5,586 & 46.8 & 286,342 & 14.2 & 5.1 \\
\hline 1996 & 5,430 & $\Delta 2.8$ & 265,560 & $\Delta 7.2$ & 4.9 \\
\hline 1997 & 5,115 & $\Delta 5.8$ & 243,013 & $\Delta 8.5$ & 4.8 \\
\hline 1998 & 6,865 & 34.2 & 203,877 & $\Delta 16.1$ & 2.9 \\
\hline 1999 & 6,801 & $\Delta 0.9$ & 251,787 & 23.5 & 3.7 \\
\hline 2000 & 6,811 & 0.1 & 301,153 & 20.0 & 4.4 \\
\hline 2001 & 6,373 & $\Delta 6.4$ & 296,355 & $\Delta 1.6$ & 4.6 \\
\hline 2002 & 5,918 & $\Delta 7.1$ & 327,075 & 10.4 & 6.1 \\
\hline 2003 & 5,343 & $\Delta 9.7$ & 334,335 & 2.2 & 6.3 \\
\hline 2004 & 6,053 & 13.3 & 377,521 & 12.9 & 6.2 \\
\hline 2005 & 5,793 & $\Delta 4.3$ & 423,538 & 12.1 & 7.3 \\
\hline 2006 & 5,759 & $\Delta 0.6$ & 502,943 & 18.7 & 8.7 \\
\hline 2007 & 6,093 & 5.8 & 659,866 & 31.2 & 10.8 \\
\hline 2008 & 9,719 & 59.5 & 731,220 & 10.8 & 7.5 \\
\hline 2009 & 9,782 & 0.7 & 766,333 & 4.8 & 7.8 \\
\hline 2010 & 10,321 & 5.5 & 869,679 & 13.5 & 8.4 \\
\hline 2011 & 12,397 & 20.1 & $1,015,982$ & 16.8 & 8.2 \\
\hline 2012 & 13,448 & 8.5 & $1,110,244$ & 9.3 & 8.3 \\
\hline 2013 & 14,303 & 6.4 & $1,250,093$ & 12.6 & 8.7 \\
\hline
\end{tabular}

Statistics of Ministry of Culture 2014. 


\section{Future Development of Korean Casino}

In modern times, the casino began to recognize as the tourism industry and the casino industry has evolved its size and shape. Back then casino industry only referred as only casino, but nowadays of casino industry has evolved in the form of an integrated resort that houses gaming area, theme park, convention centers, and other tourist attractions (Lee et al., 2011).

Recently, the growth of Macau's Casino industry is remarkable. Even 10 years ago, Las Vegas was known as the best city for casino, but handed over to Macau.

Since 2003, The Chinese people are allowed to travel freely over Hong-Kong and Macau and main customers of Macau casinos are people from China. Macau is currently the only licensed gambling area in China. The official count of the gambling revenue in Macau in 2013 is 450 billion dollars (about 45.9 trillion won) and it's the world's largest casino market after Las Vegas in United States. Over the last 30 years, the annual average growth rate of Macau's gambling industry has reached over $20 \%$, but now the situation has changed. The revenue of Macau casinos in last year of June showed downward trend for the first time in 5 years. Chinese VIP customers accounted for approximately $60 \%$ of the gambling revenue have significantly declined due to slowdown in economic growth and reinforcement of regulation on money laundry (Park \& Chung, 2014).

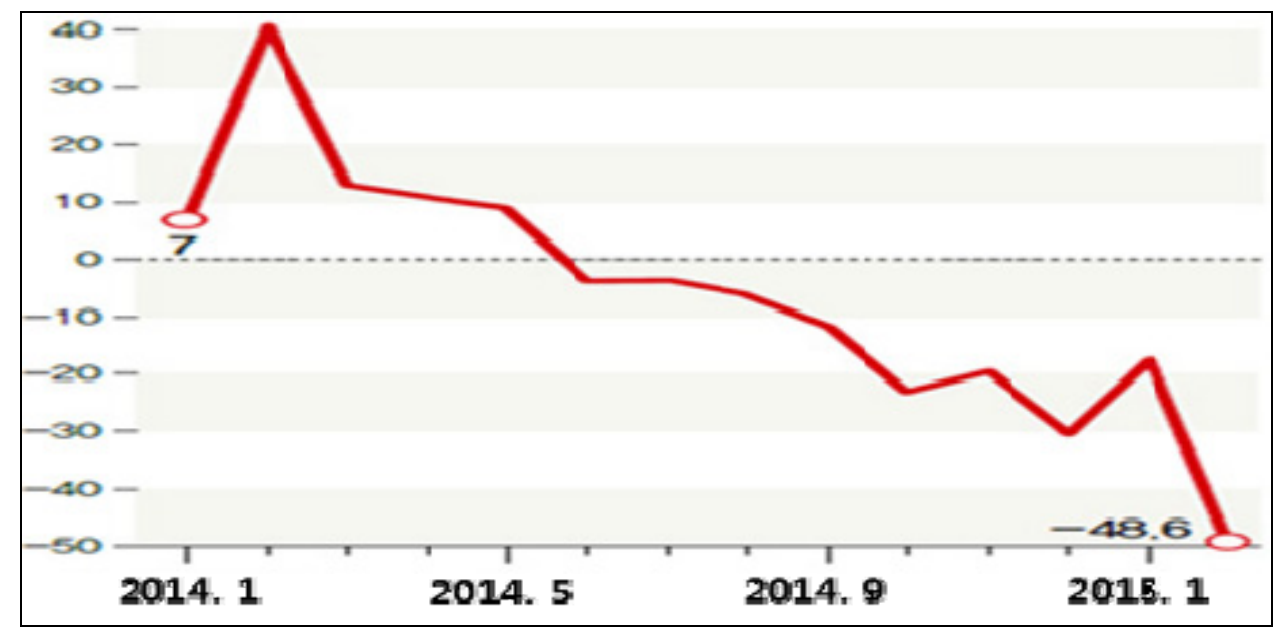

Figure 2. Earning Trend of Macau Casino

Recently, Macau began to falter due to Chinese government of Pre Xi Jinping's anti-corruption movement. According to Macau's Gaming Inspection and Coordination Bureau (DICJ), total revenue for the casino industry in Macau last month recorded 19.5 billion Pataca (about 34 million dollars). It is almost decreased nearly half (48.6\%) against those recorded in last year of February, 38 billion Pataca (Pataca is the currency in Macau. Also referred to as MOP) and this is monthly the biggest drop in history and the recovery would be difficult to improve in anytime soon. $<$ Bloomberg $>$ predicted that revenue of Macau casinos would be decreased by $8 \%$ this year. According to $<$ South China Morning Post $>$ of Hong Kong, approximately $30 \%$ of Macau casino closed down for a number of reasons. In fact, Xi Jinping's fight against corruption is damaging South Korea's economy. Sales of the largest casino company, Paradise is decreased by $3.3 \%$, year-on-year to $27.2 \%$. Especially, during the same time period the revenue of Paradise Casino in Macau fell sharply by $48.6 \%$. This is the evidence that our country has been affected by Chinese customers. 
However, Macau is trying to rise as a hub of casino by creating a huge casino town near Manila. Casino operator Melco Crown Entertainment, which is headquartered in Macau, has opened the "City of Dreams Manila" with 380 gaming tables and 3 hotel buildings. The reason Macau is creating casino town near Manila is because Manila has a low tax rate and free from surveillance by Chinese government.

Korea also expects to receive benefits from this and the job skill of Korean casino employees are world class. Our education level and the skill of dealing are better than other countries and should be differentiated through maximization of professional training. We need to develop a place where the whole family can enjoy a wide range of services by provide variety of events at the casino. Especially Singapore has developed in combination with the MICE industry and the casino industry, MICE industry is a complex industry including for basic elements: meeting, incentives, convention, and exhibition (Seo \& Lee, 2013).

The biggest current issue related to casino in our country is about a local casino to attract residents. We had already identified various issues and growth potential of locals through Kangwon Land Casino. Hence, local casino inevitably has a significant impact on the area. Although we already identified the positive impact on the local casino, we have to take cautiously on the various problems. This is because the advantages mentioned above may also cause side effects.

In order to solve the issues of casino, we need to maintain the institution of casino and amend the law related to gambling. Thus, national assembly has proposed an appropriate regulation of the casino industry through revising laws (Kim \& Chung, 2012).

Congressman, Hweson Kim, committee of Congress of Education, Culture, Sports, and Tourism announced that the congress proposed the Amendment of Tourism Promotion Act include the establishment of 'Casino Supervisory Board'. The contents of the amendment includes: $\Delta$ establishment of casino supervisory board to manage and supervise the casino, $\Delta$ obligation of prior authorization in transfer and acquisition of casino stocks, $\Delta$ strengthening eligibility requirement for shareholders and officers of casino business operator, $\Delta$ to improve transparency in reorganizing the management and supervision of judicial police power (Lee \& Kim, 2015).

In this situation, eventually the construction of additional casinos seems to be assured, but what really matter is how we preceded the casino business. Hence, we must have an arbiter to keep order in the casino industry through the strengthening of organization that can control and be prepared for a broad range of issues by realignment of a law. In addition, there are still negative images of casino industry in our country, but we need to draw positive images through establishing a solid operation policy. Casino is no longer operating by gambling and drinking, but it is part of integrated resort that has wide range of amenities. Today's casino industry will play a major role in the acquisition of foreign currency only if all plans are made.

\section{Conclusion}

Although the casino is very attractive industry in tourism, it could cause serious side effects in our society. Whether the success or failure of the casino industry will be determined in the next few years. The casino in Yeongjong Island is already under construction and plans to open in 2017. However, it's in situation where foreign capital has proposed a condition of approval of local casino. Now it is necessary to foresight the future. After all, wise decision depends on the actual state of our country. In this situation, the intellectuals need to suggest the appropriate direction through a variety of research 
In South Korea, due to expectations of additional casino construction, many areas hope to host the casino. It means that they are expecting the positive impact of the casino. Attracting casino industries is not only concerning about economic effects through the increase of additional employment and revenue. Casino industry can be included as tourism because of the increase in economic value of the surrounding area in connection with the development of commercial areas, enhancing the related area due to increase of economic trends, and the development of related industries to maintain the casino industry. However, the ripple effect is so enormous that Korean companies as well as foreign companies want to attract the casino in our country

Through the construction of Kangwon Land, we confirmed how effective the casino would be and we also identified problems and improvements. Eventually our challenge is to solve problems of economic development regard to casino. The research is required to improve the image of the casino industry and to maximize the economic effect. There are a different variety of casinos in other countries. If we just copy their casino system, our casinos will not be able to improve. It also important to learn the know-how from companies in other countries, but should be reflected to match the country situation. Foreign tourists may turn their back if we only emphasize characteristics of the country. In other words, appropriate balance is required. We are living in an age of globalization. The future of casino industry cannot be bright if we only accept foreign tourists. The development of the tourism industry in our country can attract a lot of tourists and find a variety of pleasure through the casino, but also, tourists could visit Korean casino and may have our tourism experience naturally. This situation can lead to the development of tourism industry and it will be the real reason for the construction of an additional casino.

\section{References}

Kang, M. H., \& Yook, P. L. (2010). Casino Management. Seoul: Paeksan Publishing.

Kim, G. H., Lee, D. J., \& Yu, D. J. (2013). Casino Management. Seoul: Daewang Publishing.

Kwon, G. T. (2015). Introduction of Open Casino. Busan-Ilbo. Retrieved from http://news20.busan.com

Kim, S. H., \& Chung, E. Y. (2012). The Effect of Nationality and Travel Behavior of Customers on Casino Sales Using A Quantile Regression Model: Focused on The G Casino in Korea. Korean Journal of Tourism and Leisure, 24(7), 355-370.

Lee, C. G., Song, H. J., \& Lee, D. E. (2011). Market Segmentation of Casino Visitors: Case of Japanese Chinese Tourists of Korea. Korea Journal of Hotel Administration, 20(1), 159-172.

Park, Y. R. (2015). Xi Jinping. Stumbling of Macau Casino. Hankyoreh News. Retrieved from http://www.hani.co.kr

Lee, C. K., \& Kim, N. H. (2015). Integrated resort casino, Analysis of Strategic Factors and Priority for Developing Integrated Resort Casino Using AHP. Journal of Tourism Studies, 39(2), 69-84.

Park, H. M., \& Chung, K. Y. (2014). The Effect of Physical Environment on Chinese-speaking Casino Customers' Satisfaction: The Moderating Effect of Membership Grade in Macau Casinos. Korean Journal of Hospitality and Tourism, 23(3), 259-278.

Seo, W. S., \& Lee, M. J. (2013). An Effect of the Perception of Benefits on Attitude toward Integrated Casino Facility Development. Korean Journal of Hospitality and Tourism, 22(4), 19-35. 
Yoon, J. H. (2013). Global Casino Management. Seoul: Hanol Publishing.

Song, H. J., Byun, J. W., \& Lee, C. K. (2014). Korea Casino`s Development Plan for Casino Market Change. Korean Journal of Tourism Management, 29(5), 1-22.

\section{Copyright Disclaimer}

Copyright reserved by the author(s).

This article is an open-access article distributed under the terms and conditions of the Creative Commons Attribution license (http://creativecommons.org/licenses/by/3.0/). 